\title{
Why do referees end their careers and which factors determine the duration of a referee's career?
}

\author{
Christian Rullang ${ }^{1, *}$, Eike Emrich¹ \& Christian Pierdzioch² \\ 1 Department of Sportscience, , Saarland University, Saarbrücken, Germany \\ 2 Department of Economics, Helmut-Schmidt-University, Hamburg, Germany \\ * Corresponding author: Department of Sport Science, Saarland University , Campus B8 1, 66123 Saarbrücken, Germany \\ Email: c.rullang@mx.uni-saarland.de
}

\section{ORIGINAL ARTICLE}

\section{Article History:}

Submitted 23 $3^{\text {rd }}$ June 2017

Accepted $5^{\text {th }}$ September 2017

Published $2^{\text {nd }}$ November 2017

Handling Editor:

Otmar Weiß,

University of Vienna, Austria

Editor-in-Chief:

Martin Kopp

University of Innsbruck, Austria

\section{ABSTRACT}

Against the background that the number of referees has been falling in recent years, the German Football Association (DFB) needs to answer two key questions: (i) Why do referees end their careers, and, (ii) which factors determine the duration of a referee career? We studied these questions using data from a questionnaire study of former referees. Results of estimating linear regression models and a Cox model show that the duration of a typical referee career depends, among other factors, on whether a referee thinks that his or her career is developing according to plan, and on whether a referee is successful in coping with insults, threats, and violence. The "survival rate" of a referee increases in the subjective evaluation of the importance of football-specific know-how. Approximately $39 \%$ of the former referees stated that the end of their referee career could have been prevented.

Keywords:

football referee - career duration - end of career - survey data

Reviewers:

Reviewer 1: anonymous

Reviewer 2: Bernd Frick,

University of Paderborn, Germany

Citation:

Rullang, C., Emrich, E. \& Pierdzioch, C. (2017). Why do referees end their careers and which factors determine the duration of a referee's career?. Current Issues in Sport Science, 2:006. doi: 10.15203/CISS_2017.006

\section{Introduction}

Referees and umpires are essential for many sporting competitions because they are a neutral party that monitors players' compliance to the rules of the game. A particularly large number of referees and linesmen officiate at football matches in Germany. With football being the most popular sports in Germany, the German Football Association (Deutscher FußballBund, DFB) is the largest sports association in Germany with approximately 6.9 million members organised in 25,324 clubs (see DFB, 2015a). Not a single match, and the DFB organises matches for approximately 162,000 teams in different leagues, could take place without a referee, and the winner of each sin- gle match only can be determined if the rules of the DFB apply to every team in the league and in every match.

In total, 71,521 referees were registered with the DFB as of January $1^{\text {st }} 2015$, including 2,543 female referees. However, the official referee statistics (see DFB, 2015b) reveal that, in recent years, an absolute annual decrease in total numbers has taken place since 2011 despite the fact that more than 8,000 new referees have been recruited and trained every year. The decrease in the number of referees is a major problem for the DFB because match operations and league competitions can only be maintained if the number of referees remains sufficiently large. While the DFB and the state-football associations are responsible for the training of referees and the organisation of a 
referee-monitoring system, the football clubs must delegate a certain number (depending on the number of their teams) of members to act as referees, and the clubs must support the referees by financing their training and/or equipment (kit, tickets, etc.). The result of the interplay between the DFB and the football clubs is a multi-level process that aims at making sure that the number of referees is sufficiently large. Maintaining this process is particularly difficult when, as has been the case in Germany in recent years, media reporting of violence against referees make it rather unattractive to become a football referee (for examples of media reports, see Dürr, 2012; Eberle \& Neumann, 2012; Owen, 2016).

Against this background, we studied empirically why German football referees end their career. We also studied factors that determine the duration of a referee career. While most of the earlier literature has used data on active referees, we looked at former referees. We paid particular attention to experiences of insults, threats, and violence as factors that may motivate a referee to end his or her career. While our empirical results are of essential importance for the DFB, its state associations, and for German football clubs, our empirical results should be equally interesting for football associations in other countries.

\section{Earlier research}

In recent years, several researchers have analysed stress, burnout, and coping strategies among sports officials in different sports (see Taylor \& Daniel, 1987; Rainey, 1995a, 1995b; Rainey \& Hardy, 1999; Taylor, Daniel, Leith \& Burke, 1990; Teipel, Kemper \& Heinemann 1998, 2001; Voight, 2009). Results shed light on the influence of numerous factors of stress (i.e., interpersonal conflicts, time pressure, fear of physical harm, etc.) on the intention to end a referee career. Sources of stress (see for example Rainey \& Hardy, 1999) like interpersonal conflicts and time pressure are correlated with burnout experiences and age, and burnout experiences are linked to turnover thoughts. Taylor et al. (1990) report indirect effects of fear of failure, role-culture, and interpersonal conflict on the intention to quit. According to results reported by Dosseville, Rioult and Laborde (2013) the decision to continue officiating is linked to a reason for starting officiating: the needs and obligation for sport clubs and sport associations. Interpersonal conflicts, such as threats and verbal aggressions, or a lack of commitment to the sport (no other function such as player, coach, or supervisor) (see Dosseville et al., 2013, p.8) can have negative effects on referees' motivation and their performance.

Potential causes of stress, and thus, reasons for why referees end their careers could be experiences of insults, threats, and violence. Several recent studies have shed light on the extent to which referees are victims of insults, threats, and violence (see Lützenkirchen, 2002, 2003; Vester, 2012, 2013, 2014; Rullang, Emrich \& Pierdzioch, 2015a). Vester (2013) finds for a sample of 2,602 referees of the DFB that many referees feel insulted during refereeing $(13.4 \%$ of the referees state that they have never experiences insults), while referees experienced less often threats (61.6\% have never experiences threats) or violence $(82.7 \%$ have never been a victim of violence). Rullang et al. (2015a) find similar results using data from a questionnaire study of active football referees in Germany.

Frick (2011) analyses the career duration of Bundesliga referees, where the sample period covers the seasons from 1964 to $2008 / 2009$. The average career duration for such referees is 6.3 years (see Frick, 2011, p. 489), but $18 \%$ drop out of the Bundesliga after their first season. The duration of the career of a Bundesliga referee depends on the number of matches refereed and age at the beginning of a referee career.

According to Furst (1991), there is an ideology of challenge, fitness, and competence among referees. Gray and Wilson (2008) examine the relationship between commitment to an organisation, relatedness between officials, and the willingness to continue the role of an official over the next two years in $\mathrm{Ca}$ nadian track and field. The results show that the commitment to a sport association has only a minor influence on the intention to continue as compared to the relatedness to the group of officials and the role commitment.

Results of a study of the National Association of Sports Officials (NASO) ${ }^{1}$ show that the main reason for quitting officiating in the first five years are career and job concerns. In addition "... poor sportsmanship by participants, then by spectators, time away from friends and family, low game fees, and relationship with assignors" are top reasons for quitting officiating (see Sabaini, 2001, p. 15).

Other studies address issues related to the recruitment and retention of referees (see VanYperen, 1998; Titlebaum, Haberlin \& Titlebaum, 2009; Wicker \& Frick, 2016). VanYperen (1998) shows that enjoyment is linked to the decision to continue refereeing. In addition, fairness of the promotion system and increases in rewards for refereeing (or cost decreases) could reduce turnover among referees, Wicker and Frick (2016) examine the effect of role models for the recruitment and retention of football referees. They find a significant positive trickle-down effect of role models.

Johansen (2015) shows that passion-based motives play an important role for professional referees, while physical fitness is an important motive for referees who act in amateur leagues (for an interview-study with top-level referees, see Schnyder \& Hossner 2016; for physical performance and decision making, see Mascarenhas, Button, O'Hara \& Dicks, 2009). Building on earlier research on voluntary work (Emrich, Pierdzioch \& Balter, 2013; Flatau, Emrich \& Pierdzioch 2015; Emrich \& Pierdzioch, 2015), Emrich, Pierdzioch and Rullang (2016) study the motives of active DFB referees from an economic perspective, where they differentiate between altruistic motives (public-goods model) and non-altruistic motives (private-consumption model and human-capital model). They show that particularly those referees who interpret their refereeing as a voluntary

1 For details, see http://www.naso.org/about-naso/history/ (accessed August 15). 
activity tend to have stronger altruistic motives than those referees who do not see their refereeing as a voluntary activity. Consistent with the public-goods model of volunteering, referees with strong altruistic motives often express that they are willing to end their career in case their club can recruit a sufficiently large number of other referees.

Rullang, Emrich and Pierdzioch (2015b) study the self-perception of referees, particularly the factors that referees think are important for being a good referee. In their study, they differentiate between four factors (knowledge of the rules and confident demeanour; interpretation of the rules and specific refereeing know-how; physique, and personal appearance) that play an important role in this regard. Across all league levels, knowledge of the rules and confident demeanour is the most important factors. While the significance attributed to the factor physique increases in the league level the importance attributed to personal appearance and interpretation of the rules does not display a uniform tendency in this regard. Rullang, Emrich and Pierdzioch (2015b) discuss the role of authority as a specific form of respected power for the acceptance of the referee on the field, building on earlier research by Emrich and Papathanassiou (2003). They differentiate between functional, institutionally derived, and personal authority. Functional authority includes knowledge of rules and confident demeanour as well as interpretation of the rules and knowledge from refereeing experience, i.e., special knowledge and skills in accordance with Hartmann's (1964) concept of functional authority. Personal authority comprises the factors physique and personal appearance.

\section{Methods}

Former referees in four football state associations ${ }^{2}$ within the DFB were asked questions concerning their referee activity, building on an earlier questionnaire study by Rullang et al. (2015a). The online questionnaire was available between January 23th and March 16th 2014. The former referees were contacted by the state associations, which encouraged them to participate in the survey. A total of 1,148 former referees ${ }^{3}$ participated in the questionnaire. The questionnaire comprised a total of five topic blocks (recruitment, course of career, problems and pressures, drop out, and sociodemographic data). ${ }^{4}$

2 In Germany, there are 21 state associations that are responsible for the organization of football matches up to the regional leagues. The football clubs are members of the state associations.

3 The four state associations had 8,290 e-mail addresses of former referees. We do not have information on how many former referees did not receive the e-mail.

4 Details on key questions can be found at the end of the paper (Appendix).

\section{Results}

Several authors have shed light on factors that determine the recruitment, retention and dropping out of referees in different sports. Most of these authors, however, have derived their results based on data for active referees, whereas we report in this research results based on data for former referees. The referees who took part in our questionnaire study ended their referee career between the years 2000 and 2013. They refereed at all league levels within the DFB ( 3 worked on the FIFA level, 16 on the DFB level, 45 on the national, 193 on the state level, 365 on the regional level and 496 on the district level). On average, they refereed $8.41( \pm 9.06)$ years. The average age when starting refereeing was $22.03( \pm 9.63)$ and the average age at the end of the referee career was $29.95( \pm 14.21)$ years. In total, $38.68 \%$ of the referees stated that the end of their career could have been prevented. A total of 60 referees changed their state association during their career. The change was unproblematic for 40 of these referees, while 20 reported problems (i.e., a refereeleague licence was not accepted by the new state association; referees had to restart again refereeing at the lowest league level; no matches were allocated to them).

\section{Which factors trigger the end of referees' careers?}

The referees were asked about the reasons for why they had ended their careers. The reasons are shown, separately for those referees who stated that the career end could have been prevented and those who stated that the career end could not have been prevented, in Table 1.

For those referees who stated that the end of their career could have been prevented the top reasons for dropping out are problems with representatives of the football association. Other frequently mentioned reasons for dropping out within this group are an unjustified or perceived subjective assessment of their refereeing performance, professional or private reasons, being insulted, and insufficient compensation for expenses. For those referees who stated that the end of their referee career could not have been prevented the top reasons for their career end are professional or private reasons. Only $7.21 \%$ of these referees mentioned problems with the representatives of the association.

\section{Which factors determine the duration of referees' careers?}

In a first step, we estimated linear regression models to examine factors that determine the duration of a refereeing career. Due to the explorative character of our study, we estimated a total of five models, where models differ in terms of the explanatory variables being considered. Model 1 only features personal factors, Model 2 also includes factors related to the experiences made during a referee career, Model 3 adds factors related to the assessment of the referee career, Model 4 adds experiences 
Table 1: Reasons for ending refereeing

\begin{tabular}{|c|c|c|}
\hline & $\begin{array}{c}\text { Departure could have been } \\
\text { prevented }\end{array}$ & $\begin{array}{l}\text { Departure could not have } \\
\text { been prevented }\end{array}$ \\
\hline $\mathrm{N}$ & 429 & 680 \\
\hline Reasons for dropping out & Percentage & Percentage \\
\hline Problems with responsible persons (referee observers) & 43.59 & 7.21 \\
\hline Professional reasons & 26.11 & 46.47 \\
\hline Unjustified/subjective assessment of refereeing performance & 23.78 & 5.74 \\
\hline Private reasons & 22.14 & 39.26 \\
\hline Did not want to be insulted any longer & 22.14 & 17.65 \\
\hline Insufficient compensation & 21.45 & 10.88 \\
\hline Wanted more time for other hobbies & 21.21 & 28.38 \\
\hline Not considered for promotion & 20.98 & 2.94 \\
\hline Other & 18.18 & 13.68 \\
\hline Lost interest & 14.22 & 15.59 \\
\hline Experienced violence & 6.76 & 1.91 \\
\hline Injury & 6.06 & 17.21 \\
\hline Could not withstand the pressure & 5.13 & 3.97 \\
\hline Age limit & 2.8 & 5.29 \\
\hline
\end{tabular}

Table 2: Descriptive statistics

\begin{tabular}{ccccccc}
\hline Variable & Scale & Obs. & Mean & Std. Dev. & Min. & Max. \\
\hline Change of state association & 3-Point-scale & 503 & 1.07 & 0.33 & 1 & 3 \\
Violence & 3-Point-scale & 503 & 1.19 & 0.45 & 1 & 3 \\
Course of career & 5-Point-scale & 503 & 2.86 & 1.19 & 1 & 5 \\
Training & 5-Point-scale & 503 & 2.63 & 1.61 & 1 & 5 \\
Match class (league level) & 6-Point-scale & 503 & 5.47 & 0.75 & 2 & 6 \\
Active footballer & 6-Point-scale & 503 & 3.84 & 1.76 & 1 & 6 \\
Sex & dichotomous & 503 & 1.92 & 0.25 & 1 & 2 \\
Desire for promotion & dichotomous & 503 & 1.19 & 0.46 & 1 & 2 \\
Family member was a referee & dichotomous & 503 & 1.17 & 0.37 & 1 & 2 \\
Age at start & metric & 503 & 21.06 & 8.96 & 14 & 55 \\
Age at departure & metric & 503 & 29.25 & 13.26 & 15 & 72 \\
Invested time & metric & 503 & 7.74 & 5.97 & 0 & 60 \\
\hline
\end{tabular}


with insults, threats, and violence ${ }^{5}$, and Model 5 includes motives for starting refereeing and the functional and personal authority as additional factors. ${ }^{6}$ Table 2 depicts summary statistics of all variables being used in the regression models.

In a second step, we estimated Cox models (see Cox, 1972) and computed Kaplan-Meier survival curves for the significant explanatory variables. In total, we could estimate the linear regression models and the Cox model on 503 data, after removing missing data. ${ }^{8}$

Table 3 summarises the estimation results for the linear regression models. Model 1, which features personal factors like gender, age, and the proportion of expenses to income, has only a limited explanatory power (adjusted $\mathrm{R}^{2}=0.06$ ). The explanatory power increases when we included the experience as an active football player in the regression model (Model 2). Results for Model 3 show that, as one would have expected, promotion to the professional level has a significant positive effect on the duration of a referee career. Those referees who reach the professional level ${ }^{9}$ start refereeing at the amateur level and move up in the rankings, which takes time. Additionally, those who work

5 The variables victimization and threats $(\mathrm{N}=503)$ are distributed as follows: totally unaffected ( $\mathrm{N}=200)$, threatened at least once $(\mathrm{N}=220)$, attacked physically at least once $(\mathrm{N}=5)$, threatened at least once and physically attacked $(\mathrm{N}=78)$.

6 As additional factors (motives for starting refereeing, functional and personal authority) the average of the factor values of a factor analysis has been used: motives for starting refereeing 0.8431 [std. deviation 0.3079], functional authority 0.8400 [std. deviation 0.0882 ], and personal authority: 0.8040 [std .deviation 0.0926]. See also Rullang et al (2015b).

7 The exact wording of the 3/5/6-point-scales is available upon request at the authors.

8 Further analyses showed that the referees that are lost due to missing data are not significantly different from the referees that we used to estimate the regression models with respect to key socioeconomic variables (age, income, family status, activity as a football player before/while being a referee).

9 Professional level: FIFA-list, DFB-list, or national level. In the model there are only 10 persons (1 DFB-list, 9 national level; no international level) who have refereed at the professional level. for a short time as a referee only referee at the amateur level. Results for Model 4 show that the effect of becoming a victim of threats or violence is only small (increase of the $\mathrm{R}^{2}$ from Model 3 to Model 4: 0.02). In Model 5, some personal characteristics have no significant influence on the duration of a referee's career. Conversely, both the evaluation of the level of expenses and the assessment that a referee's career did not run as planned have significant explanatory power. Duration is negatively linked to a higher level of expenses relative to income. While a referee's labour supply curve can assume complex functional form depending on substitutability and income effects, this result perhaps simply reflects that a low income implies that a referee cannot afford spending much time on refereeing. Duration decreases, as one would have expected, when a referee's career did not run as planned.

Active playing experience also has a significant influence on career duration. Particularly those referees who had played football before becoming a referee and who had 'sacrificed' their football career for their refereeing by stopping playing remain referees for a longer time than those who have had never played football. Moreover, the forms of authority have a significant influence on the duration of a referee's career as do the variable 'threatened at least once and physically attacked'. Problems that referees encounter when changing state association also seems to play a role.

Table 4 summarises the estimation results for the Cox model. We report results for two models. For Model 2, we clustered standard errors at the level of the state associations to account for the possibility that the regional football associations differ with respect to their recruiting and retention strategies. Estimation results (Table 4) are similar to the estimation results for the linear regression model (Table 3, Model 5) with regard to the significance of the coefficients. The list of significant explanatory variables includes sex, the proportion of expenses to income, whether a referee played football before starting the referee career and then stopped playing for the referee career, whether a referee career developed as planned, whether a referee has reached the professional league level, whether a referee

Table 3: Results of linear regressions

\begin{tabular}{|c|c|c|c|c|c|}
\hline & Model 1 & Model 2 & Model 3 & Model 4 & Model 5 \\
\hline Age at start & $\begin{array}{c}0.115^{* *} \\
(2.73)\end{array}$ & $\begin{array}{c}0.0936^{*} \\
(2.29)\end{array}$ & $\begin{array}{c}0.117^{* *} \\
(2.92)\end{array}$ & $\begin{array}{c}0.117^{* *} \\
(2.96)\end{array}$ & $\begin{array}{c}0.0162 \\
(0.37)\end{array}$ \\
\hline Sex (female) & Ref. & Ref. & Ref. & Ref. & Ref. \\
\hline Male & $\begin{array}{c}4.749 * * * \\
(3.33)\end{array}$ & $\begin{array}{l}3.060^{*} \\
(2.26)\end{array}$ & $\begin{array}{l}3.109^{*} \\
(2.39)\end{array}$ & $\begin{array}{c}2.523+ \\
(1.96)\end{array}$ & $\begin{array}{c}2.196+ \\
(1.77)\end{array}$ \\
\hline Proportion of expenses to income (in \%) & $\begin{array}{c}-0.0634^{* *} \\
(-2.84)\end{array}$ & $\begin{array}{c}-0.0629^{* *} \\
(-3.00)\end{array}$ & $\begin{array}{c}-0.0570^{* *} \\
(-2.81)\end{array}$ & $\begin{array}{c}-0.0522^{* *} \\
(-2.61)\end{array}$ & $\begin{array}{c}-0.0469^{*} \\
(-2.41)\end{array}$ \\
\hline Family member was already a referee (No) & Ref. & Ref. & Ref. & Ref. & Ref. \\
\hline
\end{tabular}




\begin{tabular}{|c|c|c|c|c|c|}
\hline & Model 1 & Model 2 & Model 3 & Model 4 & Model 5 \\
\hline Yes & $\begin{array}{l}0.504 \\
(0.52)\end{array}$ & $\begin{array}{l}0.847 \\
(0.93)\end{array}$ & $\begin{array}{l}0.887 \\
(1.02)\end{array}$ & $\begin{array}{l}0.680 \\
(0.79)\end{array}$ & $\begin{array}{l}0.862 \\
(1.04)\end{array}$ \\
\hline Played football (never played) & & Ref. & Ref. & Ref. & Ref. \\
\hline Played football before becoming a referee & & $\begin{array}{l}3.173^{*} \\
(2.23)\end{array}$ & $\begin{array}{l}3.438^{*} \\
(2.53)\end{array}$ & $\begin{array}{l}3.174^{*} \\
(2.36)\end{array}$ & $\begin{array}{l}2.569^{*} \\
(1.97)\end{array}$ \\
\hline Played football during entire referee career & & $\begin{array}{l}0.851 \\
(0.55)\end{array}$ & $\begin{array}{l}2.300 \\
(1.56)\end{array}$ & $\begin{array}{l}2.017 \\
(1.39)\end{array}$ & $\begin{array}{l}1.127 \\
(0.80)\end{array}$ \\
\hline $\begin{array}{l}\text { Played football before starting to referee and stopped } \\
\text { playing for the referee career }\end{array}$ & & $\begin{array}{c}6.672^{* * *} \\
(4.26) \\
\end{array}$ & $\begin{array}{c}6.852^{* * *} \\
(4.58) \\
\end{array}$ & $\begin{array}{c}6.233^{* * *} \\
(4.22)\end{array}$ & $\begin{array}{c}5.387^{* * * *} \\
(3.76)\end{array}$ \\
\hline $\begin{array}{l}\text { Played before starting to referee and stopped playing for } \\
\text { other reasons }\end{array}$ & & $\begin{array}{c}4.775^{* *} \\
(2.85)\end{array}$ & $\begin{array}{c}5.364^{* * *} \\
(3.36)\end{array}$ & $\begin{array}{c}4.667^{* *} \\
(2.95)\end{array}$ & $\begin{array}{l}3.494^{*} \\
(2.26)\end{array}$ \\
\hline Course of referee career (completely as planned) & & & Ref. & Ref. & Ref. \\
\hline Mostly as planned & & & $\begin{array}{l}-1.777 \\
(-1.63)\end{array}$ & $\begin{array}{c}-1.825+ \\
(-1.68)\end{array}$ & $\begin{array}{l}-1.554 \\
(-1.48)\end{array}$ \\
\hline Partly as planned & & & $\begin{array}{l}-1.329 \\
(-1.19)\end{array}$ & $\begin{array}{l}-1.100 \\
(-0.99)\end{array}$ & $\begin{array}{l}-0.949 \\
(-0.88)\end{array}$ \\
\hline Hardly as planned & & & $\begin{array}{l}-3.099 * * \\
(-2.71)\end{array}$ & $\begin{array}{l}-2.954^{* *} \\
(-2.60)\end{array}$ & $\begin{array}{l}-2.680^{*} \\
(-2.41)\end{array}$ \\
\hline Not at all as planned & & & $\begin{array}{l}-3.196^{*} \\
(-2.28)\end{array}$ & $\begin{array}{l}-3.336^{*} \\
(-2.41)\end{array}$ & $\begin{array}{l}-3.380^{*} \\
(-2.52)\end{array}$ \\
\hline Yes, with problems & & & $\begin{array}{l}4.930^{*} \\
(2.16)\end{array}$ & $\begin{array}{c}4.145+ \\
(1.84)\end{array}$ & $\begin{array}{c}3.982+ \\
(1.83)\end{array}$ \\
\hline Invested time: ... hours per week & & & $\begin{array}{c}0.107+ \\
(1.82) \\
\end{array}$ & $\begin{array}{c}0.0766 \\
(1.32) \\
\end{array}$ & $\begin{array}{c}0.0746 \\
(1.32) \\
\end{array}$ \\
\hline victimization (totally unaffected) & & & & Ref. & Ref. \\
\hline Threatened at least once & & & & $\begin{array}{c}1.176 \\
(1.61)\end{array}$ & $\begin{array}{l}0.723 \\
(1.02)\end{array}$ \\
\hline Attacked physically at least once & & & & $\begin{array}{c}5.998+ \\
(1.80) \\
\end{array}$ & $\begin{array}{l}4.945 \\
(1.53) \\
\end{array}$ \\
\hline Threatened at least once \& physically attacked & & & & $\begin{array}{c}4.366^{* * *} \\
(4.32) \\
\end{array}$ & $\begin{array}{c}4.152^{* * *} \\
(4.25)\end{array}$ \\
\hline Altruistic motive & & & & & $\begin{array}{l}1.702 \\
(1.50)\end{array}$ \\
\hline Functional authority & & & & & $\begin{array}{c}27.14^{* * * *} \\
(5.45)\end{array}$ \\
\hline
\end{tabular}




\begin{tabular}{|c|c|c|c|c|c|}
\hline Personal authority & & & & & $\begin{array}{c}-8.978+ \\
(-1.94) \\
\end{array}$ \\
\hline Constants & $\begin{array}{l}1.830 \\
(1.13) \\
\end{array}$ & $\begin{array}{l}2.189 \\
(1.12)\end{array}$ & $\begin{array}{l}1.061 \\
(0.50) \\
\end{array}$ & $\begin{array}{l}0.825 \\
(0.39)\end{array}$ & $\begin{array}{c}-12.91^{* * * *} \\
(-3.52)\end{array}$ \\
\hline $\mathrm{R} 2$ & 0.063 & 0.192 & 0.282 & 0.312 & 0.363 \\
\hline Adjusted R2 & 0.055 & 0.177 & 0.257 & 0.283 & 0.332 \\
\hline
\end{tabular}

t Statistic in brackets;

$+p<0.10,{ }^{*} p<0.05,{ }^{* *} p<0.01,{ }^{* * *} p<0.001$

Table 4: Results of duration model (Cox-Regression)

(1)

\section{Cox Model}

\begin{tabular}{|c|c|c|}
\hline Age at start & $\begin{array}{c}-0,00394 \\
(-0,59)\end{array}$ & $\begin{array}{c}-0,00697 \\
(-1,04)\end{array}$ \\
\hline Sex (female) & $\begin{array}{l}0 \\
(.)\end{array}$ & $\begin{array}{l}0 \\
(.)\end{array}$ \\
\hline Male & $\begin{array}{l}-0,705^{* * *} \\
(-3,78)\end{array}$ & $\begin{array}{c}-0,700^{* * *} \\
(-3,68)\end{array}$ \\
\hline Proportion of expenses to income (in \%) & $\begin{array}{c}0,00966^{* * *} \\
(3,40)\end{array}$ & $\begin{array}{c}0,00938^{* *} \\
(3,19)\end{array}$ \\
\hline $\begin{array}{l}\text { Family member was already a referee } \\
\text { (No) }\end{array}$ & $\begin{array}{l}0 \\
(.)\end{array}$ & $\begin{array}{l}0 \\
(.)\end{array}$ \\
\hline Yes & $\begin{array}{l}-0,191 \\
(-1,53)\end{array}$ & $\begin{array}{l}-0,259^{*} \\
(-2,01)\end{array}$ \\
\hline Played actively (never played) & $\begin{array}{l}0 \\
(.)\end{array}$ & $\begin{array}{l}0 \\
(.)\end{array}$ \\
\hline Played before role as referee & $\begin{array}{r}-0,376^{+} \\
(-1,96) \\
\end{array}$ & $\begin{array}{c}-0,371^{+} \\
(-1,92) \\
\end{array}$ \\
\hline Played during entire referee career & $\begin{array}{l}-0,113 \\
(-0,56)\end{array}$ & $\begin{array}{l}-0,253 \\
(-1,20)\end{array}$ \\
\hline $\begin{array}{l}\text { Played football at the start and stopped } \\
\text { playing for the referee role }\end{array}$ & $\begin{array}{l}-0,665^{* *} \\
(-3,17)\end{array}$ & $\begin{array}{c}-0,744^{* * *} \\
(-3,48)\end{array}$ \\
\hline $\begin{array}{l}\text { Played football at the start and stopped } \\
\text { playing for other reasons }\end{array}$ & $\begin{array}{l}-0,333 \\
(-1,47)\end{array}$ & $\begin{array}{l}-0,485^{*} \\
(-2,09)\end{array}$ \\
\hline Still an active player & $\begin{array}{l}0,310 \\
(1,62)\end{array}$ & $\begin{array}{l}0,136 \\
(0,69)\end{array}$ \\
\hline $\begin{array}{l}\text { Course of referee career (completely as } \\
\text { planned) }\end{array}$ & $\begin{array}{l}0 \\
(.)\end{array}$ & $\begin{array}{l}0 \\
(.)\end{array}$ \\
\hline Mostly as planned & $\begin{array}{l}0,178 \\
(1,14)\end{array}$ & $\begin{array}{l}0,158 \\
(1,00)\end{array}$ \\
\hline Partly as planned & $\begin{array}{l}0,102 \\
(0,64)\end{array}$ & $\begin{array}{c}0,0906 \\
(0,55)\end{array}$ \\
\hline
\end{tabular}




\begin{tabular}{|c|c|c|}
\hline & Cox Model & $\begin{array}{c}\text { Cox Model With Standard Errors Clustered } \\
\text { at the Regional Level }\end{array}$ \\
\hline Hardly as planned & $\begin{array}{l}0,327^{*} \\
(1,96) \\
\end{array}$ & $\begin{array}{l}0,340^{*} \\
(1,98) \\
\end{array}$ \\
\hline Not at all as planned & $\begin{array}{c}0,582^{* *} \\
(2,94)\end{array}$ & $\begin{array}{l}0,570^{* * *} \\
(2,87) \\
\end{array}$ \\
\hline Highest level (amateur sector) & $\begin{array}{l}0 \\
0 \\
(.)\end{array}$ & $\begin{array}{l}0 \\
0 \\
(.)\end{array}$ \\
\hline Professional sector & $\begin{array}{l}-0,770^{* * * *} \\
(-3,41)\end{array}$ & $\begin{array}{l}-0,665^{* *} \\
(-2,92)\end{array}$ \\
\hline Change of state assoc. (No) & $\begin{array}{l}0 \\
(.)\end{array}$ & $\begin{array}{l}0 \\
(.)\end{array}$ \\
\hline Yes, without problems & $\begin{array}{l}-0,503^{+} \\
(-1,82) \\
\end{array}$ & $\begin{array}{l}-0,603^{*} \\
(-2,06) \\
\end{array}$ \\
\hline Yes, with problems & $\begin{array}{l}-0,344 \\
(-1,08)\end{array}$ & $\begin{array}{l}-0,521 \\
(-1,61)\end{array}$ \\
\hline Invested time: ... hours per week & $\begin{array}{c}-0,0148^{+} \\
(-1,66) \\
\end{array}$ & $\begin{array}{r}-0,0101 \\
(-1,10) \\
\end{array}$ \\
\hline victimization (totally unaffected) & $\begin{array}{l}0 \\
(.) \\
\end{array}$ & $\begin{array}{c}0 \\
(.) \\
\end{array}$ \\
\hline Threatened at least once & $\begin{array}{l}-0,217^{*} \\
(-2,09) \\
\end{array}$ & $\begin{array}{l}-0,227^{*} \\
(-2,18) \\
\end{array}$ \\
\hline Physically attacked at least once & $\begin{array}{l}-0,520 \\
(-1,10) \\
\end{array}$ & $\begin{array}{l}-0,476 \\
(-1,00) \\
\end{array}$ \\
\hline $\begin{array}{l}\text { Threatened at least once and physically at- } \\
\text { tacked }\end{array}$ & $\begin{array}{c}-0,552^{* * * *} \\
(-3,88)\end{array}$ & $\begin{array}{c}-0,588^{* * * *} \\
(-4,12) \\
\end{array}$ \\
\hline Altruistic motive & $\begin{array}{l}-0,267 \\
(-1,50) \\
\end{array}$ & $\begin{array}{l}-0,182 \\
(-0,98) \\
\end{array}$ \\
\hline Functional authority & $\begin{array}{l}-3,847^{* * * *} \\
(-5,18)\end{array}$ & $\begin{array}{l}-3,758^{* * * *} \\
(-5,06)\end{array}$ \\
\hline Personal authority & $\begin{array}{l}1,410^{*} \\
(2,07) \\
\end{array}$ & $\begin{array}{l}1,304^{+} \\
(1,89) \\
\end{array}$ \\
\hline Observations & 502 & 497 \\
\hline
\end{tabular}

t statistics in parentheses;

$+p<0.10,{ }^{*} p<0.05,{ }^{* *} p<0.01,{ }^{* * *} p<0.001$

could change from one state association to another without problems, whether a referee was the victim of threats and/or physical attacks, and (functional) authority. Clustering the standard errors affects the significance of the coefficients only in a few cases (for example, the coefficient that captures whether a family member was already a referee becomes significant while the significance of the coefficient estimated for the influence of personal authority weakens).

The Cox model has the advantage that we can compute Kaplan-Meier survival curves to illustrate our empirical results. Figure 1 shows (for the model without clustered standard errors) the Kaplan-Meier curves for the explanatory variables that refer to the experience as an active football player and the assessment of the course of the referee career. In the left panel, the survival rates assume the largest value for those referees who gave up their football career for refereeing, that is, those referees who very likely made a 'sacrifice' for refereeing. The survival rates for the group of referees who are still active as football players and for those referees who never played football are comparatively the lowest. In the right panel, the survival rates are largest for those referees who stated that their career had progressed (completely) as planned. The survival rates are lowest for those referees who stated that their career had not progressed at all according to their plans.

Figure 2 shows the survival rates for the variables 'change in state association' (left panel) and 'victimization' (right panel). Referees who had changed the state association during their career stayed on average for a longer time than referees who had never changed. An interesting result is that the survival rate is higher for those referees for whom the change involved 


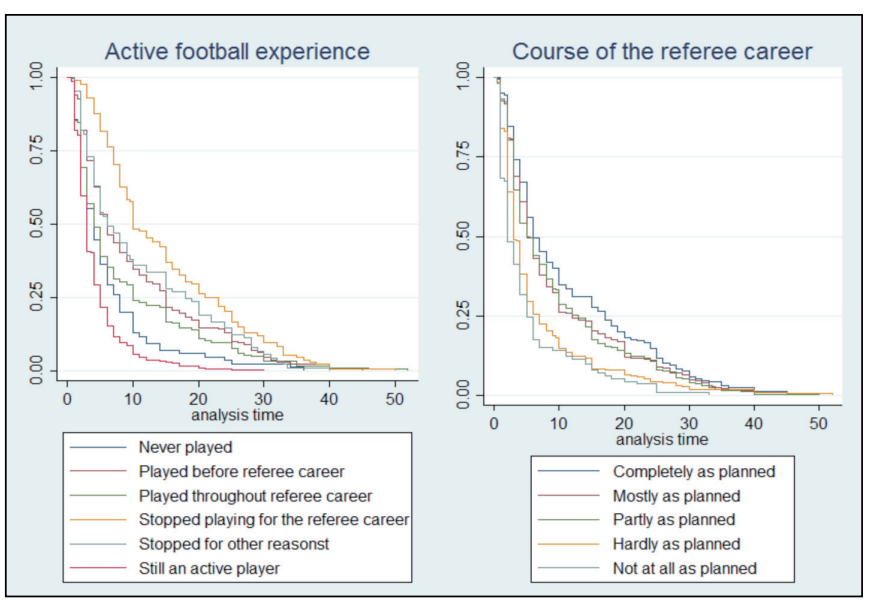

Figure 1: Kaplan-Meier survival curves for the variables active player experience and course of the refereeing career

problems than for those who did not encounter problems. An explanation for this result is that the occurrence of problems (that is, bureaucratic obstacles) drives ambition, so that the activity is continued because of the problems that were mastered. With regard to the variable victimization, the survival rate increases from 'totally unaffected' to 'threatened at least once and physically attacked'. In this regard, it seems that those referees who had experienced threats or violence have developed coping strategies (see Vester, 2013; Rullang et al., 2015a).

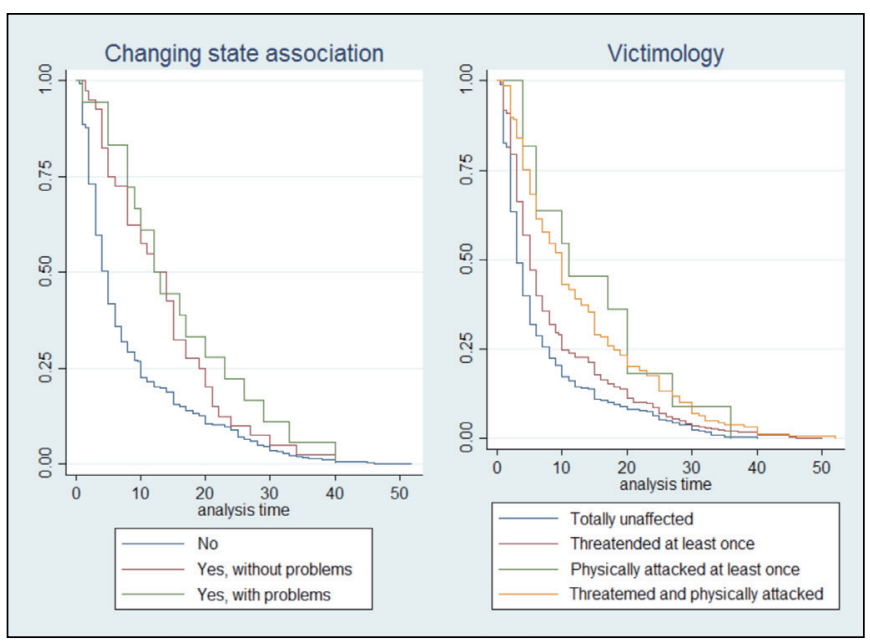

Figure 2: Kaplan-Meier survival rates for the variables change of state association and becoming a victim

Figure 3 summarises the influence of several other variables. For computing the figure, the variables 'invested time' and 'personal and functional authorities' were summarised in four categories. The category limits were placed at the quartile limits of each variable. The survival rate (see figure 3 top left) for male referees is higher than for female referees. Those referees who spent a lot of time (more than 10 hours per week) on their referee activity have the lowest survival rates while we observe the highest rates for those referees who spent between one and three hours per week on refereeing. Considerations regarding time restrictions and the opportunity costs of refereeing, thus, seem to play a role for the decision to continue refereeing. Referees who reach the professional level (see Footnote 5) stay on average longer than referees who stay in the amateur sector (moving up in the rankings takes time).

The survival curves shift upward as the subjective values of personal and functional authority increase. Those referees who state that functional authority is particularly important have the highest survival rate. Thus, a special referee-specific knowledge, trained and accumulated in many games, combined with a high level of conscientiousness increases the duration of a referee career.

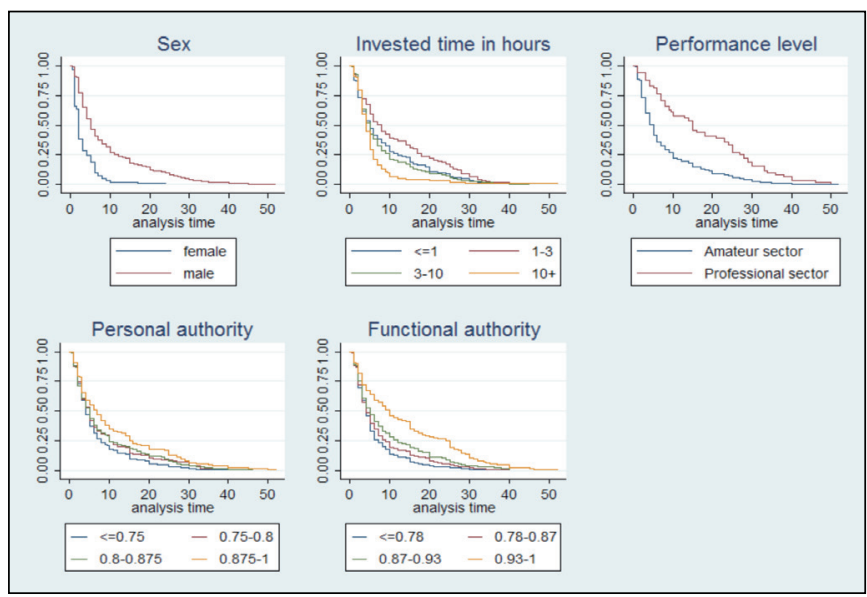

Figure 3: Kaplan-Meier survival rates for the variables sex, invested time, performance level, personal and functional authority

\section{Discussion}

Referees are essential for any league and cup match organised by football associations. Referees ensure that the rules are upheld during every game and, thus, that championship and cup competitions can take place. League and cup competitions would not be possible without a neutral party, the referee. A key problem of the German football association is that, according to official statistics, the number of referees has been decreasing in recent years, even though a substantial number of referees have been recruited and trained every year.

We studied the reasons for why former referees ended their career and we analysed factors that determine the duration of a referee career. Approximately $39 \%$ of the former referees stated that the end of their referee career could have been prevented. While one should take into account when interpreting these results that people who quit a job would likely say their departure could have been prevented (which does not necessarily mean it could), it is interesting to note that personal problems with the representatives of the associations (like referee observers), professional reasons, and a subjective impression that performance assessments were not justified were named frequently by referees as reasons for why they ended their refe- 
ree career. Some of the reasons for departure could be resolved in part by the associations, for example, by appointing a contact person for referees who referees can contact in case they encounter problems with representatives of the associations. Another possibility is that football associations establish a commission, formed by officials of the associations and representatives of the referees, that develops proposals for a reform of the system for the promotion and relegation of referees.

As for the referees who stated that their departure could not have been prevented, our results show that professional and private reasons are important for why referees end their careers. This may depend on biographical factors. Marriage and birth of children take often place in this phase of life, consuming a large proportion of an indivudual's time budget. Moreover, the decision to end refereeing may be easier to make for referees who never have played soccer and who have a lower commitment to soccer. Consistent with these considerations, the Kaplan-Meier survival curves demonstrate that, with the exception of those referees who had stopped playing football in order to start refereeing and who eventually have reached the professional sector, many referees end refereeing in the first few years. These dropouts are particularly problematic for the associations and the clubs because the time and money invested in the training of the referees is lost. Such referees could perhaps be convinced to continue refereeing if there was a possibility to take a timeout, which is already possible in some places, or if the number of matches could be reduced on short notice for certain periods and the DFB could implement a programme for the recruitment of referees who ended refereeing some years before.

The Kaplan-Meier curves further show that referees who have no experience as active football players have the lowest "survival rates" while those referees who stopped playing football in order to take up a refereeing position have the highest "survival rates". Thus, it would be advisable for a successful, longer-term recruitment of new referees to contact active players who may be at the end of their active playing career, or who no longer have the opportunity to invest time in training during the week, but who would like to stay with football. In this regard, it is interesting to note that the highest survival rates can be observed for those referees who invest a total of one to three hours per week in the refereeing position. This is substantially less than active players generally invest.

With regard to victimization an interesting result is that referees who became victims of threats and violence have the highest survival rates. This result may indicate that these referees have learnt to cope with such negative experiences. For referee training, this means that football associations should prepare the referees for this kind of scenario.

The trainee referees should also be shown realistic courses of 'referee careers' during their training. Those referees who had careers that ran according to continued their referee career for a longer time than those referees whose careers had not developed according to plan.
Our results further show that those referees for whom functional authority is particularly important for a good referee have a higher survival rate than those referees for whom functional authority is not of great importance. This is also a point that should be noted in the training of new referees. Knowing about their function and their significance for the game and the competition appears to strengthen referees and helps to reduce the probability of them dropping out. Hence, our empirical results indicate that the duration of referee careers could be extended through changes of the training system.

\section{Funding}

The authors have no funding or support to report.

\section{Competing Interests}

The authors have declared that no competing interests exist.

\section{Data Availability Statement}

All relevant data are within the paper.

\section{References}

Cox, D. R. (1972). Regression Models and Life Table (With Discussion). Journal of the Royal Statistical Association, 72, 557565.

DFB (2015a). Mitglieder-Statistik 2015. (Statistics of Members 2015) Available at http://www.dfb.de/fileadmin/ dfbdam/66210-Mitglieder-Statistik_2015.pdf (accessed 05.10.2017)

DFB (2015b). Schiedsrichter-Statistik 2015. (Statistics of Referees 2015) Available at http://www.dfb.de/index. php?id=1004747 (accessed 05.10.2017)

Dohmen, T. J. (2008). The Influence of Social Forces: Evidence from the Behavior of Football Referees. Economic Inquiry, $46,411-424$.

Dosseville, F, Rioult, F. \& Laborde, S. (2013). Why Do Sorts Officials Dropout? Proceedings Machine Learning and Data Mining for Sports Analytics workshop at ECML/PKDD, 1-10.

Dürr, B. (2012). Prügelattacke auf Linienrichter: Totschlag an der Seitenlinie. (Referee Assistant Beaten Up. Manslaughter on the Sideline). Spiegel-Online (04.12.2012). Available at http://www.spiegel.de/panorama/justiz/niederlandeunter-schock-jugendliche-pruegeln-linienrichter-zu-tode-a-870949.html (accessed 05.10.2017)

Eberle, L. \& Neumann, C. (2012). Perilous Pitches: Violence Against Referees Spikes in Germany. Spiegel-Online (14.12.2012). Available at http://www.spiegel.de/international/zeitgeist/german-football-referees-face-increasing- 
violence-at-amateur-games-a-872692.html (accessed 05.10.2017)

Emrich, E. \& Papathanassiou, V. (2003). Der Schiedsrichter als Regelüberwacher und -durchsetzer in der Institution Sportspiel. (The Referee as the Keeper of the Rules in Sports Games). Spectrum der Sportwissenschaft, 15, 6-19.

Emrich, E. \& Pierdzioch, C. (2015a). Testing Economic Models of Volunteer Labor Supply: Some Empirical Evidence for the German Red Cross. Applied Economics, 47, 4247-4259.

Emrich, E., Pierdzioch, C. \& Rullang, C. (2016). For the Love of football? Using Economic Models of Volunteering to Study the Motives of German football referees. Sport und Gesellschaft - Sport and Society, 16

Emrich, E., Pierdzioch, C. \& Balter, J. (2013). Motive ehrenamtlichen Engagements im Fußball. Eine sozio-ökonomische Analyse und das Problem sozialer Erwünschtheit (Motives of Volunteers in Football. A Socioeconomic Analysis and the Social-Desireability Problem). In H. Kempf, S. Nagel \& H. Dietl. Im Schatten der Sportwirtschaft. Schorndorf: Hofmann.

Flatau, J., Emrich, E. \& Pierdzioch, C. (2015). Zur empirischen Prüfbarkeit des homo (socio-) oeconomicus anhand der Messung der Motive ehrenamtlicher Engagements in Sportvereinen (Empirical Tests of the Homo (Socio-)Economicus Model Using Data on the Motives of Volunteers in Sports Clubs). Journal of Applied Social Science Studies, 4, 451-476.

Frick, B. (2011). Career Duration on Professional Football: The Case of German Soccer Referees. In L. H. Kahane \& S. Shmanske, The Economic of Sports. The Oxford Handbook of Sports Economics I (pp. 487-500). New York, Oxford: Oxford University Press.

Furst, D.M. (1991). Career Contingencies: Patterns of Initial Entry and Continuity in Collegiate Sports Officiating. Journal of Sport Behavior, 14, 93-102.

Gray, C.E. \& Wilson, P.M. (2008). The Relationship Between Organizational Commitment, Perceived Relatedness, and Intentions to Continue in Canadian Track and Field Officials. Journal of Sport Behaviour, 30, 44-63.

Hartmann, H. (1964). Funktionale Autorität. Systematische Abhandlung zu einem soziologischen Begriff. (Functional Authority. Systematical Review of a Sociological Term). Stuttgart: Enke.

Johansen, B.T. (2015). Reasons for Officiating Soccer: the Role of Passion-Based Motivations among Norwegian Elite and Non-Elite Referees. Movement \& Sport Sciences, 87, 23-30.

Lützenkirchen, H.-G. (2002). Aggression und Gewalt im Amateurfußball: Wahrnehmungen und Einschätzungen aus der Praxis; Ergebnisse einer Befragung von Funktionsträgern der Fußballkreise im Bereich des Fußball-Verbandes Mittelrhein e.V. (Aggression and Violence in Amateur Football). Köln: FußballVerband Mittelrhein e. V.

Lützenkirchen, H.-G. (2003). Fußball und Gewalt. (Football and Violence) In H.-J. Kerner \& E. Marks (Eds.). Internetdokumentation Deutscher Präventionstag. Hannover. Available at http://www.praeventionstag.de/nano.cms/dokumentation/details/19 (accessed 05.10.2017)
Mascarenhas, D. R., Button, C., O’Hara, D. \& Dicks, M. (2009). Physical Performance and Decision Making in Association Football Referees: A Naturalistic Study. Available at http://epubs.glyndwr.ac.uk/cgi/viewcontent. cgi?article $=1001 \&$ context $=$ ses (accessed 05.10.2017)

Owen, D. W. (2016). Violence at Children's Football Game "Out of Control" Says Leicester Ref. Leicester Mercury. Available at http://www.leicestermercury.co.uk/Violence-children-sfootball-games-control-says/story-28815391-detail/story. html (accessed 02.02.2016)

Rainey, D.W. (1995a). Sources of Stress among Basketball and Softball Umpires. Journal of Applied Sport Psychology, 7, 1-10.

Rainey, D.W. (1995b). Stress, Burnout, and Intention to Terminate among Umpires. Journal of Sport Behavior, 18, 312-323.

Rainey, D.W. \& Hardy, L. (1999). Sources of Stress, Burnout and Intention to Terminate among Rugby Union Referees. Journal of Sport Sciences, 17, 797-806.

Rullang, C., Emrich, E. \& Pierdzioch, C. (2015a). Wie häufig werden Schiedsrichter Opfer von Beleidigungen, Drohungen und Gewalt? Ergebnisse einer bundesweiten Umfrage unter aktiven Schiedsrichtern. (How Often are Referees Vicitms of Insults, Threats, and Violence? Results of a Nationwide Survey of Active Referees). Leipziger Sportwissenschaftliche Beiträge, 56, 44-66.

Rullang, C., Emrich, E. \& Pierdzioch, C. (2015b). Mit Zuckerbrot und Pfeife - Die Bedeutung unterschiedlicher Autoritätsformen im Rollenselbstbild von Schiedsrichtern (With a Carrot and a Whistle - The Importance of Differnet Forms of Authority in the Role Self-Perception of Referees). Sport und Gesellschaft - Sport and Society, 12, 215-239.

Sabaini, D. (2001). How to Get \& Keep Officials. Special Report. The National Association of Sports Officials. Available at http://www.naso.org/Resources/SpecialReports.aspx (accessed 05.10.2017)

Schnyder, U. \& Hossner, E.-J. (2016). Psychological Issues in Football Officiating: An Interview Study with Top-Level Referees. Current Issues in Sport Science, 1, 1-14.

Taylor, A. H. \& Daniel, J.V. (1987). Sources of Stress in Soccer Officiating: An Empirical Study. In T. Reilly, A. Lees, K. Davis \& W.J. Murphy (eds): Science and Football: Proceedings of the First Wolf Congress of Science and Football (pp. 538-544). London: E\& FN Spon.

Taylor, A. H., Daniel, J.V., Leith, L. \& Burke, R.J. (1990). Perceived Stress, Psychological Burnout and Paths to Turnover Intentions among Sport Officials. Journal of Applied Sport Psychology, 2, 84-97.

Teipel, D., Kemper, R. \& Heinemann D. (1998). Physiologische Beanspruchung eines Schiedsrichters im Fußball. (Physical Strain on Referees in Lower and Higher Divisions) In G. Bäumler \& G. Bauer (Hrsg.), Sportwissenschaft rund um den Fußball. (Schriften der Deutschen Vereinigung für Sportwissenschaft, 96, pp. 79-86). Hamburg: Czwalina.

Teipel, D., Kemper, R. \& Heinemann D. (2001). Psychische Beanspruchung von Schiedsrichtern in niedrigen und ho- 
hen Spielklassen. (Psychological Strain on Referees in Lower and Higher Divisions) In D. Teipel \& R. Kemper (Hrsg.), Nachwuchsförderung im Fußball. 15. Jahrestagung der dvsKommission Fußball vom 17.-19.11.1999 in Jena. (Schriften der Deutschen Vereinigung für Sportwissenschaft, 118, pp. 219-225). Hamburg: Czwalina.

Titlebaum, P. J., Haberlin, N. \& Titlebaum, G. (2009). Recruitment and Retention of Sports Officials. Recreational Sports Journal 33, 102-108.

VanYperen, N.W. (1998). Predicting Stay/Leave Behaviour among Volleyball Referees. The Sport Psychologist, 12, 427439.

Vester, T. (2012). Neue Maßnahmen gegen Gewaltvorkommnisse auf dem Fußballplatz im Amateurbereich: Eine Forschungsskizze und erste Ergebnisse. (New Policies against Violence on Amateur Football Courts: A Scientific Sketch and First Results). Neue Kriminalpolitik, 3, 92-97.
Vester, T. (2013). Zielscheibe Schiedsrichter: Zum Sicherheitsgefühl und zur Opferwerdung von Unparteiischen im Amateurfußball (1st ed.). (Referee as Target: To the Feeling of Safety and to the Victimization of Officials in Amateur Divisions). BadenBaden: Nomos.

Vester, T. (2014). Immer häufiger, immer brutaler? Ein Überblick zur Entwicklung des Gewaltaufkommens im Amateurfußball. (More Often, More Brutal? A Review of the Development of Violence in Amateur Football). Kriminalistik, 10, $572-576$.

Voight, M. (2009). Sources of Stress and Coping Strategies of US Soccer Officials. Stress and Health, 25 (1), 91-101.

Wicker, P. \& Frick, B. (2016). Recruitment and Retention of Referees in Nonprofit Sport Organizations: The Trickle-Down Effect of Role Models. Voluntas, 27, 1304-1322. 


\section{Appendix}

Key questions from the questionnaire study.

1. What are the reasons why you ended your refereeing activity?

- Problems with representatives of the association (referee observers)

- Professional reasons

- Unjustified/subjective assessment of refereeing performance

- Private reasons

- Did not want to be insulted any longer

- Insufficient compensation

- Wanted more time for other hobbies

- Not considered for promotion

- Lost interest

- Experienced violence

- Injury

- Could not withstand the pressure

- Age limit

- Other

2. Did you change your state association?

- Yes, without any problems

- Yes, with some problems

- No

3. Have you ever played actively football?

- Never played

- Played football before becoming a referee

- Played football during entire referee career

- Played football before starting to referee and stopped playing for the referee career

- Played before starting to referee and stopped playing for other reasons

- Still an active player

4. How was the course of your referee career?

- Completely as planned

- Mostly as planned

- Partly as planned

- Hardly as planned

- Not at all as planned

5. Victimization:

Combination of two questions:

- Where you ever victiom of threats?

- never

- very rarely

- rarely

- often

- very often

- Where you ever victiom of a physical attack

- No, never

- Yes, once

- Yes, more than once

Victimization:

- Totally unaffected

- Threatened at least once

- Physically attacked at least once

- Threatened at least once and physically attacked

6. Which was the highest league at which you refereed matches?

- FIFA-List

- DFB-List

- National level

- Regional level

- State level

- District level 